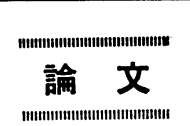

充填層内における微粉を伴つた気体の

(C) 1986 ISI

\section{2 次元流動特性}

\author{
山岡秀 行* \\ Flow Characteristics of Gas and Fine Particles in a \\ Two-dimensional Space of Packed Bed
}

Hideyuki Yamaoka

\begin{abstract}
Synopsis:
\end{abstract}
In order to evaluate the effect of powder on the blast furnace operation, the 2-dimensional behavior of gas and powder in packed bed with a tuyere on it's wall side were studied by a mathematical simulation model as well as a cold model experiment. Results obtained are as follows;

1) When the gas velocity along the wall side is decreased, powder tends to accumulate near the wall above tuyere resulting in the increase in pressure drop of gas and the decrease in gas flow rate near the wall.

2) The deterioration of gas permeability accompanied by the decrease in wall temperature at the lower part during the reduced production operation of blast furnace can be attributed to the accumulation of fine coke near the wall.

\section{1. 緒}

コークスや鉱石の粉化，高温部で生成される金属や金 属酸化物蒸気の再凝縮などの過程を経て高炉内では多種 多様の粉が発生しているが，これらの粉の一部はガス中 に混入して充填層内を移動，または局部的に蓄積し，通 気や通液性に影響を及ぼしているものと考えられる11. したがつて, 高炉内のガス流れは厳密には粉を含む固気 2 相流であり，粉の影響を評価して操業に反映させるた めには，その流動特性を的確に把握する必要がある.

固気 2 相流の研究は粉体工学の分野において進められ ている2)3). しかし，充媜層内を対象とした検討例は少な く4)，高炉のように立体的な広がりを有する充媜層に対 する検討がなされた例はみられない。

そこで, 前報5)において粉の 1 次元的流動特性を調查 し，ガス中における粉の集団を一つの相として把握し， ガスと粉との相互作用力として Ergun タイプの流体抵 抗力, 粉と充填粒子との相互作用力としては両者の衝突 に起因する粉の運動量変化を採用して運動方程式を作成 することにより粉の運動状態指標, 寸なわち流速と滞留 量を計算することができ，また，ガスと充填粒子との相 互作用力にガスと粉との相互作用力 (いずれも Ergun タイプの流体抵抗力）を加算することにより圧力損失に
及ぼす粉の影響も評価できることを示した。

ここでは, 前報の結果を 2 次元架間に拡張して数学モ デルを作成し，平板模型実験と対比してその妥当性を検 証するとともに，側壁に羽口を有する充媜層内における 粉の流動特性を調査し，高炉との関連性を考察した。

\section{2. 充填層内固気 2 相流 2 次元数学モデル}

2 次元充塤層空間におけるガスと粉の挙動を定量的に 予測することを目的として 2 次元数学モデルを作成し た.

\section{$2 \cdot 1$ 状態記述式の導出}

充塤層内における粉の状態に着目すると, 微視的には 多数の粉がそれぞれ別々の速度でガス中を運動している と考えられるが，ここでは粉の集団も一つの相であると して巨視的に把握し, ガスと粉の平均速度（流速）と滞 留量を変数としてそれぞれの運動状態を記述した.

充填層空隙内におけるガスと粉の空間占有率を示す指 標として粉の空隙率 $\varepsilon_{k}$ を定義すれば，粉拉よびガスの 滞留量 $H_{k}, H_{g}$ はそれぞれ次のように記述できる.

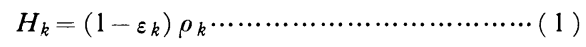

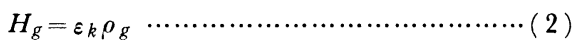

ここに, $\rho_{k}$ は粉のみかけ密度, $\rho_{g}$ はガス密度である.

粉とガスの流速として充媜層空隙断面基準の流速を採

昭和 60 年 10 月本会講演大会にて発表 昭和 61 年 1 月 27 日受付 (Received Jan. 27, 1986)

* 住友金属工業(株) 総合技術研究所鉄鋼研究センタ (Iron \& Steel Research Center, Technical Research Laboratories, Sumitomo Metal Industries, Ltd., 16 Oaza-Sunayama Hasaki-cho Kashima-gun Ibaragi pref. 314-04) 
用し， $\vec{U}_{k}, \vec{U}_{g}$ と表記すれば，質量保存の関係から，粉 とガスについて以下に示す連続の式が成立する.

$$
\begin{aligned}
& \frac{\partial}{\partial t} H_{k}+\operatorname{div} H_{k} \vec{U}_{k}=0 . \\
& \frac{\partial}{\partial t} H_{g}+\operatorname{div} H_{g} \vec{U}_{g}=0 .
\end{aligned}
$$

運動状態に着目すると, 系全体には粉, ガスおよび充 媜粒子が存在し, 別々の流速で運動（ただし，充媜䊉子 は静止）しているため, 粉とガス, ガスと充媜粒子、お よび充填粒子と粉とのあいだに相互作用力が働いてい る. 粉同土の相互.作用力も存在するが, 粒度分布のない 場合を想定すれば充填粒子との相互.作用力と比較して小 さいので,ここでは無視した.

これらの相互作用力は以下のよらに記述できる5).

1) 粉とガスとの相互作用力; $\vec{F}_{k, g}$

粉の集団を粉との相対速度で流れるガスに対して静止 した一種の充填層とみなせば Ergun タイプの流体抵抗 力を適用できる.これを 2 次元に拡張すれば, 次式を得 る.

$$
\begin{aligned}
\vec{F}_{k, g} & =150 \mu_{g}\left(\frac{1-\varepsilon_{k}}{\varepsilon_{k} \phi_{k} d_{k}}\right)^{2}\left(\vec{U}_{g}-\vec{U}_{k}\right) \\
& +1.75 \rho_{g} \frac{1-\varepsilon_{k}}{\varepsilon_{k} \phi_{k} d_{k}}\left|\vec{U}_{g}-\vec{U}_{k}\right|\left(\vec{U}_{g}-\vec{U}_{k}\right)
\end{aligned}
$$

ここに, $\phi_{k}, d_{k}$ は粉の形状係数と粒子径, $\mu_{g}$ はガス の粘性係数を示す.

2) ガスと充填粒子との相互. 作用力 ; $\vec{F}_{g, p}$

Ergun タイプの流体抵抗力を用いて以下のように記 述できる。

$$
\begin{aligned}
\vec{F}_{g, p} & =150 \mu_{g}\left(\frac{1-\varepsilon_{p}}{\varepsilon_{p} \phi_{p} d_{p}}\right) 2 \vec{U}_{g} \\
& +1.75 \rho_{g} \frac{1-\varepsilon_{p}}{\varepsilon_{p} \phi_{p} d_{p}}\left|\vec{U}_{g}\right| \vec{U}_{g}
\end{aligned}
$$

ここに, $\varepsilon_{p}$ は充填層の空隙率, $\phi_{p}, d_{p}$ は充填粒子の 形状係数と直径を示す.

3) 充填粒子と粉との相互作用力; $\vec{F}_{p, k}$

粉が静止した充填粒子へ衝突することに起因する運動 量変化と考学れば次式を適用できる。

$$
\begin{aligned}
& \vec{F}_{p, k}=\frac{3}{2} \frac{1+e_{k, p}}{1-e_{k, p}} \\
& \quad \frac{\left(1-\varepsilon_{k}\right) \rho_{k}\left(1-\varepsilon_{p}\right) \rho_{p}\left(d_{k}+d_{p}\right)^{2}}{\rho_{k} d_{k}{ }^{3}+\rho_{p} d_{p}{ }^{3}} \cdot\left|\vec{U}_{k}\right| \vec{U}_{k} \cdots
\end{aligned}
$$

ここに, $e_{k, p}$ は反発係数である.

粉の運動量保存の関係に着目すると, 粉は重力ととも にガスとの相互作用力を駆動力とし, 充填粒子との相互 作用力を運動抵抗力として運動していると考えることが
できるので，次に示す運動方程式が成立する.

$$
\frac{\partial}{\partial t} H_{k} \vec{U}_{k}=\vec{F}_{k, g}+H_{k} \vec{g}-\vec{F}_{p, k}
$$

また，ガスは圧力勾配を駆動力として流れ，粉および 充填粒子との相互.作用力が抵抗力として作用していると 考えられるので，次の運動方程式が成立する.

$$
\frac{\partial}{\partial t} H_{g} \vec{U}_{g}=-\operatorname{grad} P_{g}-\vec{F}_{k, g}-\vec{F}_{p, g}
$$

以上，(3)，(4)，(8)，および(9) 式に示された 4 個の状態記述式の独立变数は $\vec{U}_{k}, \vec{U}_{g}, P_{g}, H_{k}$ または $\varepsilon_{k}, H_{g}$ または $\rho_{g}$ の 5 個であるが，理想気体を仮定し て次に示すガスの状態方程式を併用すれば計算すること ができる.

$$
P_{g}=\rho_{g} R T_{g}
$$

ここに, $R$ はガス定数, $T_{g}$ はガス温度である.

\section{$2 \cdot 2$ 状態記述式の計算方法}

粉の滞留量分布の時間変化が他の変数の時間変化に比 べて緩慢であることに着目し，以下に示すように状態記 述式を二つのグループに分離して計算するょらにした。

A. 擬定常状態

$$
\begin{aligned}
& \operatorname{div} H_{g} \vec{U}_{g}=0 \ldots \ldots \ldots \ldots \ldots \\
& \vec{F}_{k, g}+\vec{F}_{g, p}=-\operatorname{grad} P_{g} \\
& \vec{F}_{p, k}=\vec{F}_{k, g}+H_{k} \vec{g} \ldots \ldots \ldots
\end{aligned}
$$

B. 非定常状態

$$
\frac{\partial}{\partial t} H_{k}+\operatorname{div} H_{k} \vec{U}_{k}=0
$$

B （(14) 式）は（3)式をそのまま引用した粉の滞留量 の時間变化に関する偏微分方程式であり, 粉の流速分布 を与えれば粉の滞留量分布の時間変化を計算寸ることが できる、これをBの計算とする．

一方，Aは(4)，(8)，および(9)式において時間微 分項を省略したものであるが，粉の滞留量の時間变化を 介して間接的に時間に依存するため擬定常状態と称し た．(11)，(12) 式はガスの圧力と流速に関する連立微分 方程式，(13)式は，(5)式と(7) 式を代入すればガスと 粉の流速の関係を規定する代数方程式であり，それぞれ に粉の滞留量分布を与えればガスの圧力分布と流速分

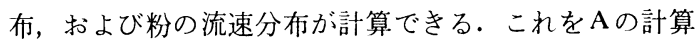
とする.

ここで, 粉の滞留量分布の変化がガスの圧力と流速お よび粉の流速に有意に影響を及ぼさない微小時間を $\Delta$ とすれば， $\Delta t$ のあいだ粉の流速分布を一定としてBの 計算を行い, $\Delta t$ 時間後の 粉の 滞留量分布を求めること ができる、また，得られた粉の滞留量分布を用いて $\mathrm{A} の$ 


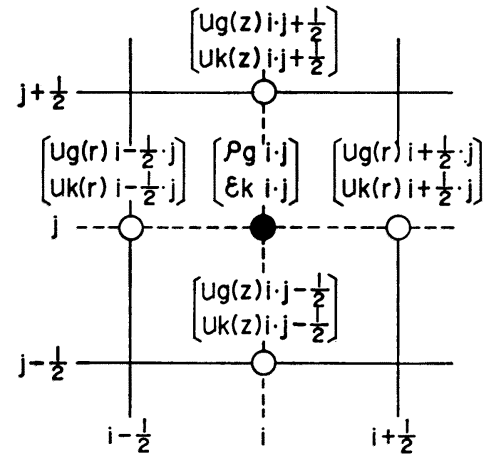

Fig. 1. Mesh structure in the mathematical simulation model.
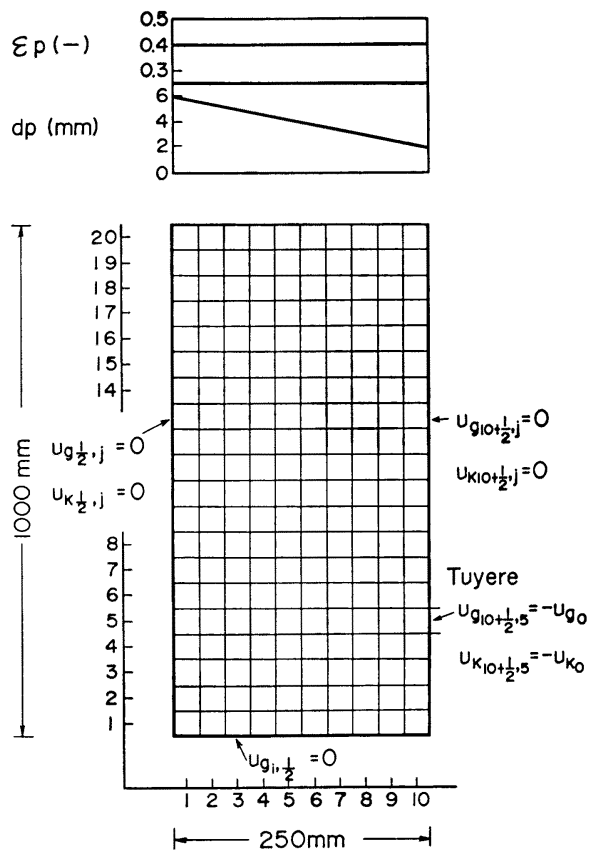

Fig. 2. Calculation conditions.

計算を行えば，その条件に対するガスの圧力分布と流速 分布，および粉の流速分布を求めることができる.した がつて, $\Delta t$ の間隔で $\mathrm{B}$ の計算と $\mathrm{A}$ の計算とを繰り返す ことにより固気 2 相流の状態の経時変化と最終的な定常 状態を求めることができる.

この計算方法では，元の状態記述式におけるガスの密 度と流速および粉の流速の時間微分項を省略しているた め, 非定常過程に対する厳密な解は期待できない。しか し, 定常状態では時間微分項が 0 となるため, この計算 方法による解は元の状態記述式の解と原則的に一致する と考えられる。

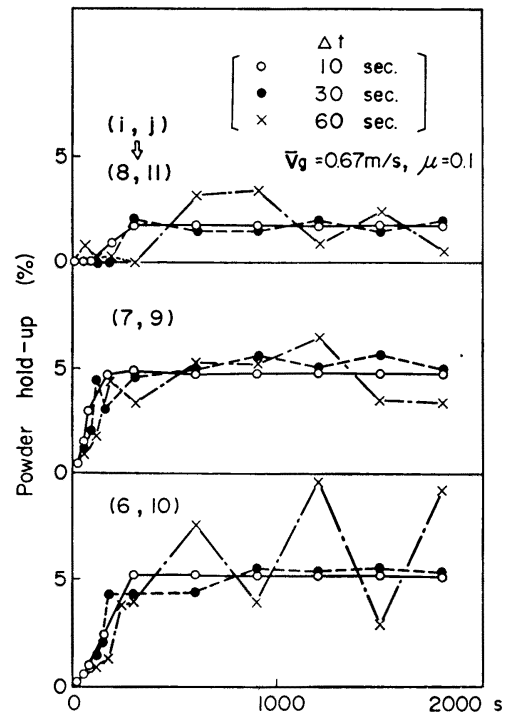

Fig. 3. Influence of the interval $(\Delta t)$ to refresh powder velocity on the calculated results of powder hold-up by the model.

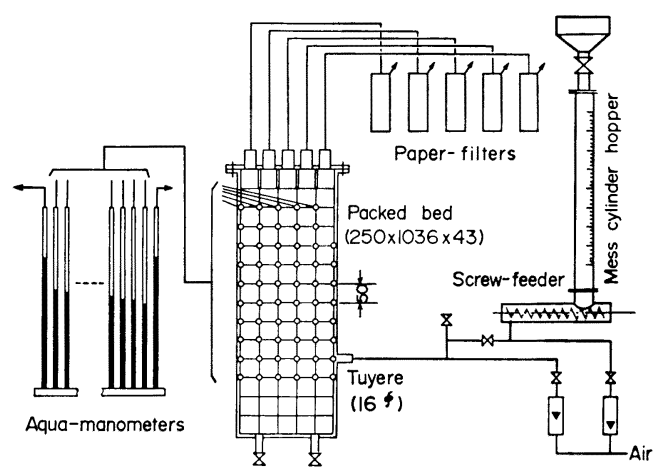

Fig. 4. Experimental apparatus.

具体的計算に際しては, Fig. 1 に示すスタッガード メッシュ構成を用いて差分方程式を作成し，(11)，(12) 式に対しては SOLA 法に準じた陰陽混成差分法6),

(14)式に対しては陽差分法を適用した.

\section{$2 \cdot 3$ 境界条件および計算例}

次章で説明する実験装置に対応させた計算のメッシュ 構成と境界条件を Fig. 2 に示す.

ガスの境界条件として，ガス流れの遮断された両側壁 と底辺に対して直角方向の流速成分を 0 ，ガスが自由に 流出する層頂に対しては，水平方向の流速成分を 0 とし た。 また，羽口に対しては，実験条件に相当する所定の 値を水平方向流速成分として設定した.

一方，粉の境界条件としては，ガスの場合と同様に両 
A
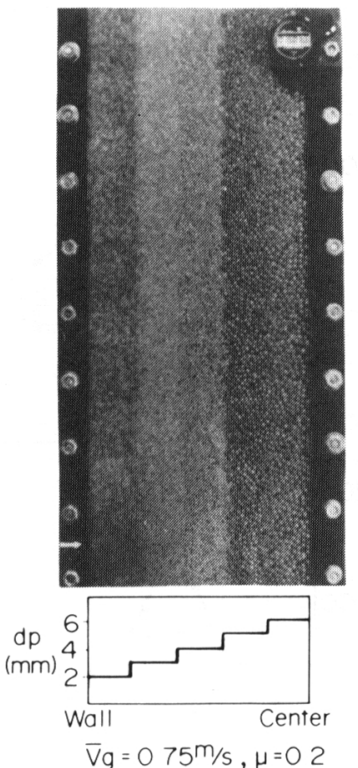

(B)
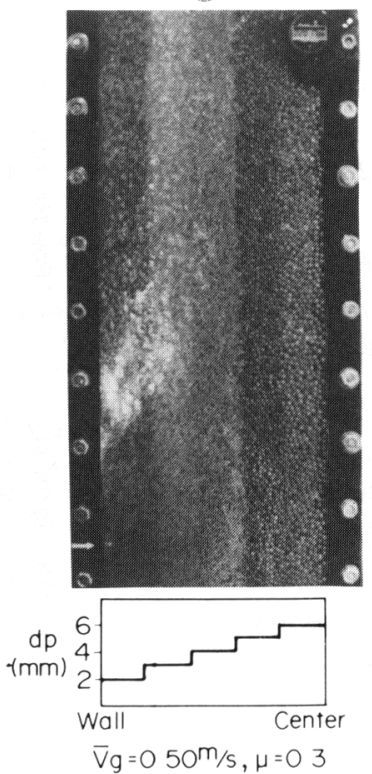

(C)
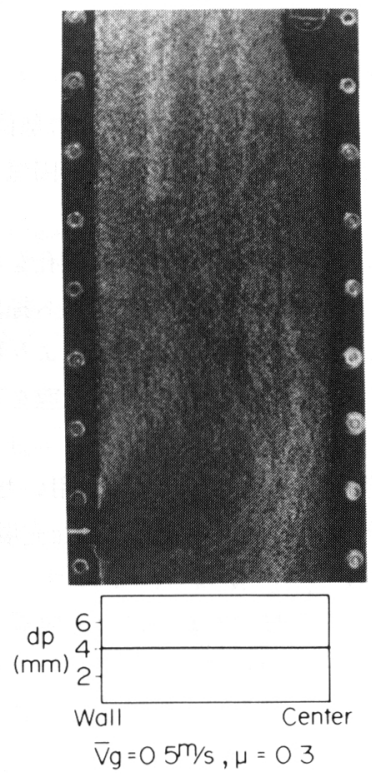

Photo. 1. Powders hold-up $15 \mathrm{~min}$ after powder injection.
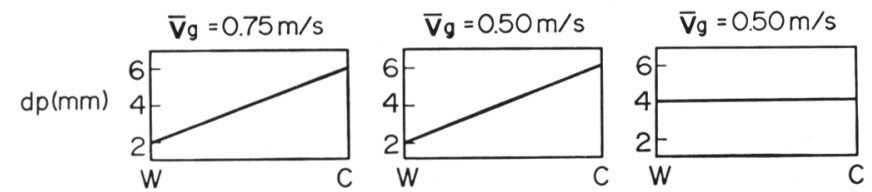

$(\mathrm{mm})$

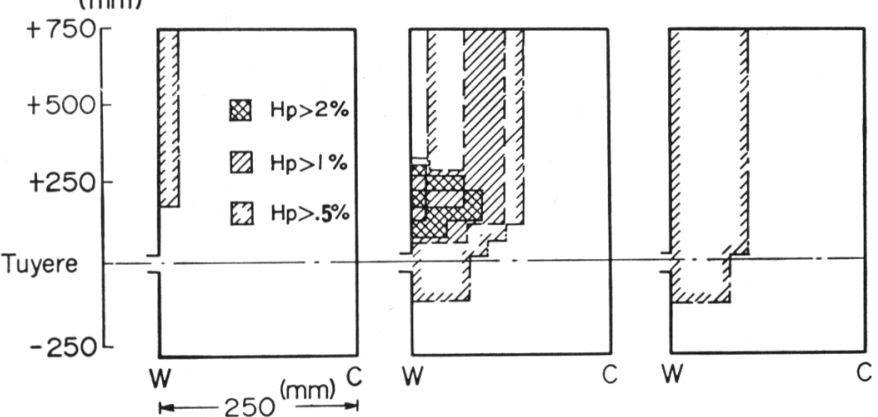

(A)

(B)

側壁に対して直角方向の流速成分を 0 , 層頂に対して水 平方向の流速成分を 0 , さらに羽口に対して実験条件に 相当する所定の值を水平方向流速成分として設定した. ただし，底辺に対しては自由流出条件を採用し，水平方 向流速成分を 0 としている. 理由は, 高炉を想定し, 炉 林に流下する粉はやがては消滅すると考えた場合に対応 させるためである、計算によると (Fig. 8, 9 参照), 羽 ロレベルから横幅の $1 / 2$ 程度下方まで流れ込さガスの 量はわずかなので, それ以下の部分に粉が蓄積しても全 体のガス流れに及ぼす影響は無視できる。したがつて,
(C)
Fig. 5. Distributions of powder holdup $\left(H_{p}\right)$ in packed bed calculated by the model.
この仮定は, 実験の場合でも, 粉が多量に下部に蓄積し ない時間内に扎いて妥当と考えられる.

Fig. 3 に代表的な格子点に拈壮る粉の滞留量の時間 変化の計算結果を示す. 粉の流速分布を更新する時間間 隔 $\Delta t$ を $10 \mathrm{~s}$ 程度に設定すれば安定な解が得られた。ま た，粉吹込及後 $300 \mathrm{~s}$ 程度で定常状態が得られている。

\section{2 次元平板模型実験}

数学モデルの妥当性の検証, および高炉を模擬した側 壁に羽口を有する充填層内における粉とガスの流動特性 
の調査を目的として平板模型実験を実施した。

\section{1 実験方法}

実験装置をFig. 4 亿示す. 本体内部に粒子を装入し て充填層とし, 側壁, 底辺 $+250 \mathrm{~mm}$ の部位に設置し た羽口から空気と粉を吹き込み，層内に固気 2 相流を形 成させた。

本体の裏面に $50 \mathrm{~mm}$ 格子間隔で静圧孔を設置して压 力分布を計測した，層頂を 5 分割したガス抽出口から空 気を回収して粉を分離, 計量することにより粉の流量分 布を求めた。 また，層内での粉の滞留状態を写真撮影し た。

粉として直径 $0.1 \mathrm{~mm}$ のガラス球を用いた. 充媜層 としては直径 $4 \mathrm{~mm}$ のガラス球の均一な充媜層と, 羽口 側から順次, 直径 $2 \mathrm{~mm}$ から $6 \mathrm{~mm}$ のガラス球を 50 $\mathrm{mm}$ の幅で充填して粒度分布をつけた充媜層の 2 種類を 用い，ガス（空気）流速を変化させて粉とガスの流動特 性を調査した。また，粉の吹込及時間は，底辺における 粉蓄積の影響を考虑し， $20 \mathrm{~min}$ 以内とした。

\section{2 実験結果}

\section{$3 \cdot 2 \cdot 1$ 粉の挙動観察結果}

Photo. 1 飞写真撮影結果を示す. A と B はガス流速 が異なる場合の対比， B と C は粒度分布のある場合と無 い場合の対比であるが，ガス流速が低く，かつ粒度分布 をつけたBの壁側（羽口側），羽口上方約 $200 \mathrm{~mm}$ の部 位に粉滞留領域（写真中，白く又える部位）が形成され た. C の写真でもやや白い粉の存在する部分が認められ るが，この領域は装置に振動を加えると消隇するもので あつた。しかし，Bの粉滞留領域は振動を加えても消減 せず，粉は常時運動しており，壁側で降下，中間部で上 昇し，全体として渦を形成している様子が観察された。

一方, 数学モデル計算結果を Fig. 5 に示す. 同じ条件 で，同じ部位に粉滞留領域 $\left(H_{p} / \rho_{k}>2 \%\right)$ が形成され ており，両者は定性的に一致している.

\section{$3 \cdot 2 \cdot 2$ 層頂に打沙粉の流量分布}

層頂水平方向の粉の流量分布を, 計算と実験とを対比 させて Fig. 6 と示す. A の場合, 粉の大半は壁側を流 れている。しかし，粉滞留領域が形成されたBの場合に は壁側の粉の流量は少なく，中間部では流量が最大にな つているまた，計算と実験は拈拈む叔一致している。

\section{$3 \cdot 2 \cdot 3$ 粉吹込丈にともなら压力分布の変化}

Bについて粉を吹き込む場合と吹き込まない場合の圧 力分布の差異を Fig. 7 に示す. 粉吹込及により圧力の レベルが上昇するが，同時に，粉滞留領域に対応する $+200 \mathrm{~mm}$ レベルで中間部に圧力のピークが形成され， $+300 \mathrm{~mm}$ レベルでは中心部 (羽口の反対側) の圧力が

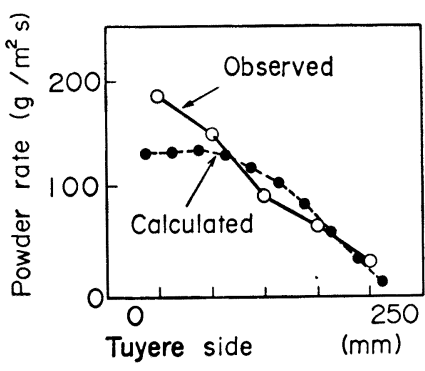

(A) $\bar{v}_{g}=0.75 \mathrm{~m} / \mathrm{s}$

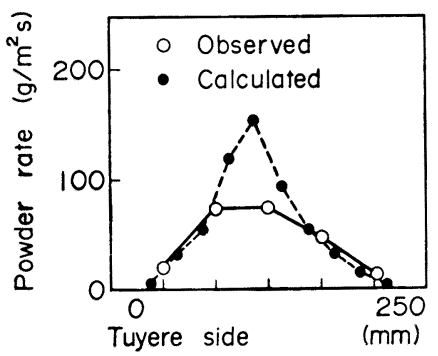

(B) $\bar{V}_{g}=0.5 \mathrm{~m} / \mathrm{s}$

Fig. 6. Powder flow rate at the top of the bed measured and calculated.

高くなつていることが特徵的である.この圧力分布から 推定すると, 粉の滞留する $+200 \mathrm{~mm}$ レベルで壁側を 避けて中心部に偏り，その上方で再度壁側に戻るよらな ガス流れが生じていると考えられる。また，ここでも計 算と実験には良好な一致関係が得られた。

以上，側壁に羽口を設置した充填層の場合，壁側が細 粒となる粒度分布でガス流速を低下させると羽口上方の 壁側に粉滞留領域の形成されることが判明した。また， 計算結果は実験結果と良く一致していることから, 本数 学モデルの妥当性も確認された.

\section{4. 考}

察

\section{1 粉とガスの 2 次元流動特性}

\section{$4 \cdot 1 \cdot 1$ 粉とガスの挙動}

ガス流速ベクトルと粉の流量ベクトルの分布の計算結 果を Fig. 8，9 飞示す. A (Fig. 8) の場合に着目する と，ガスとともに吹き込まれた粉で，上向きの気流に乗 る粉は壁側を上昇するが，中心に向から気流に乗る粉は 途中で気流から離脱して降下する。このため，壁側の粉 の流量が多くなり，Fig. 6A に示したように，層頂でも 壁側で高い分布が形成される。一方，ガス流速が低いB の場合, Fig. 9 に示すように, 上方に移行するにつれて 壁側のガス流速の垂直成分が減少して粉の搬送能力を失 


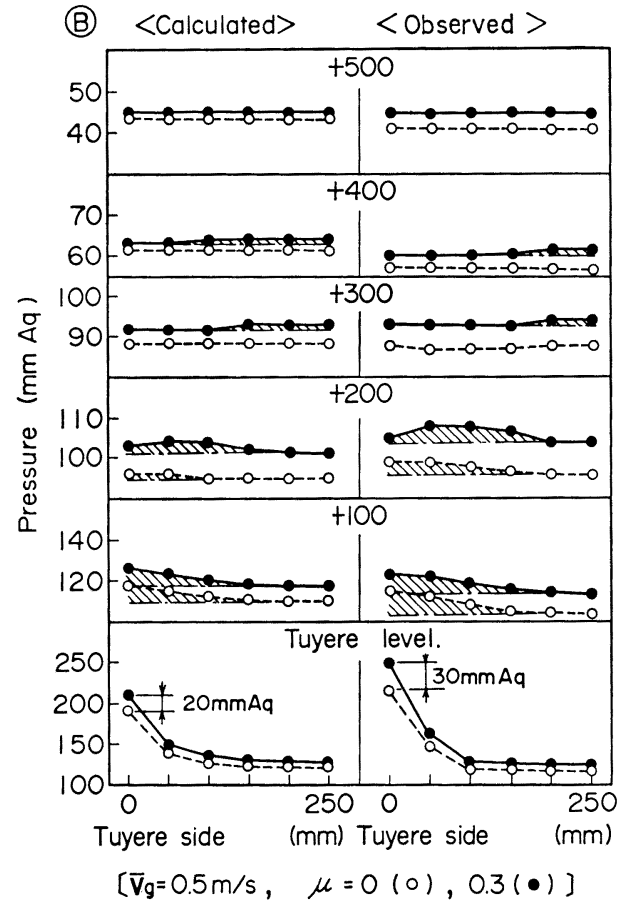

Fig. 7. Calculated and measured pressure distributions, for clean gas flow $(\mu=0)$ and gas-solid two phase flow $(\mu>0)$.

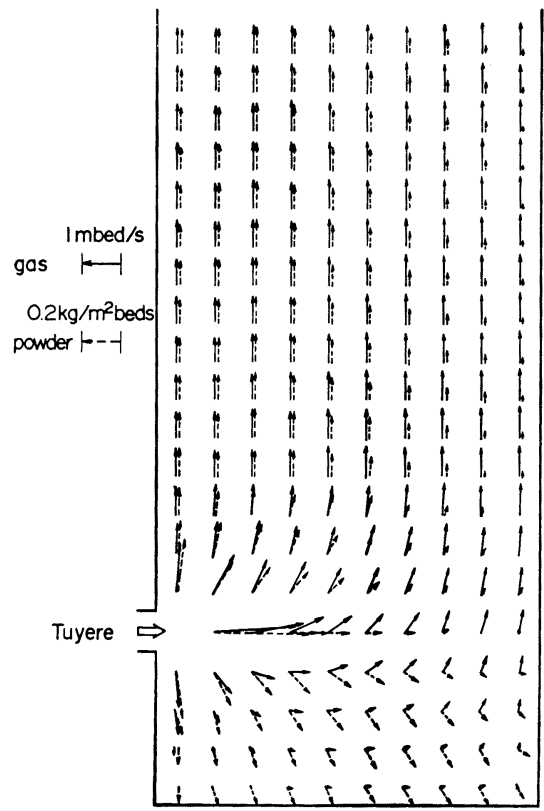

Fig. 8. Movements of gas powders in case A calculated by the mathematical simulation model.

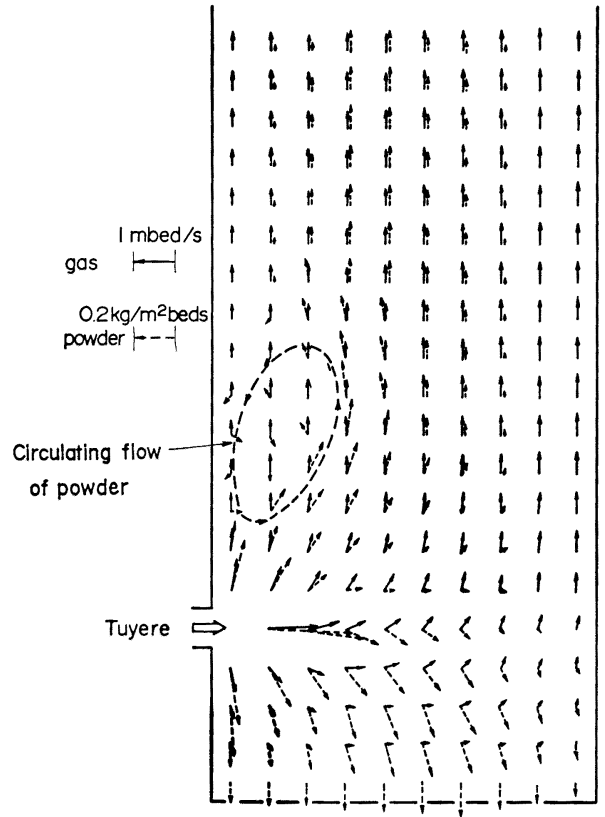

Fig. 9. Movements of gas and powder in case B calculated by the mathematical simulation model.

らと，粉はそれ以上上昇することができなくなるので， Fig. 5 に示したよらに，滞留領域を形成する。 また， この場合, Fig. 7 の圧力分布変化にも示したように，粉 滞留領域を迂回してその上方で壁側に戻るガス流れが生 じるので, 粉が中間部から持ち込まれて壁側を降下し, 粉滞留領域の回りに粉の渦を形成することになる.

\section{$4 \cdot 1 \cdot 2$ ガス流れの変化}

ガス流速垂直方向成分 $V_{g}$ の水平方向，および垂直方 向分布をFig. 10 に示す. 粉を吹き込むと $(\mu>0)$ 壁側 で粉の流量が多くなり，粉とガスとの相互作用力が大き くなるため, 羽口レベルでは, すべての場合, ガス流れ が中心流化している，A， Cの場合, 粉滞留領域が形成 されないので，層頂でも壁側のガス流速が減少し，中心 流化している，粉滞留領域が形成された Bでも，層頂の ガス流れは中心流化しているが，この場合には中間部の 流速低下と対応している，また，高さ方向の流速分布変 化から明らかなように，粉滞留領域が形成されたレベル で壁側のガス流れが著しく阻害されている。

\section{1 .3 粉滞留領域の形成条件}

Fig. 10 で, 粉吹込みのない場合 $(\mu=0)$, 羽口位置 の影響により，壁側の高さ方向流速分布は，上方へ移行 するとともに流速が低下する形になるが，中心側では上 方に移行するとともに流速が増大する形になる。また， 羽ロレベルより $0.7 \mathrm{R}$ ( $\mathrm{R}$ は横幅) 程度上方で羽口位置 
(A)

(B)

(C)
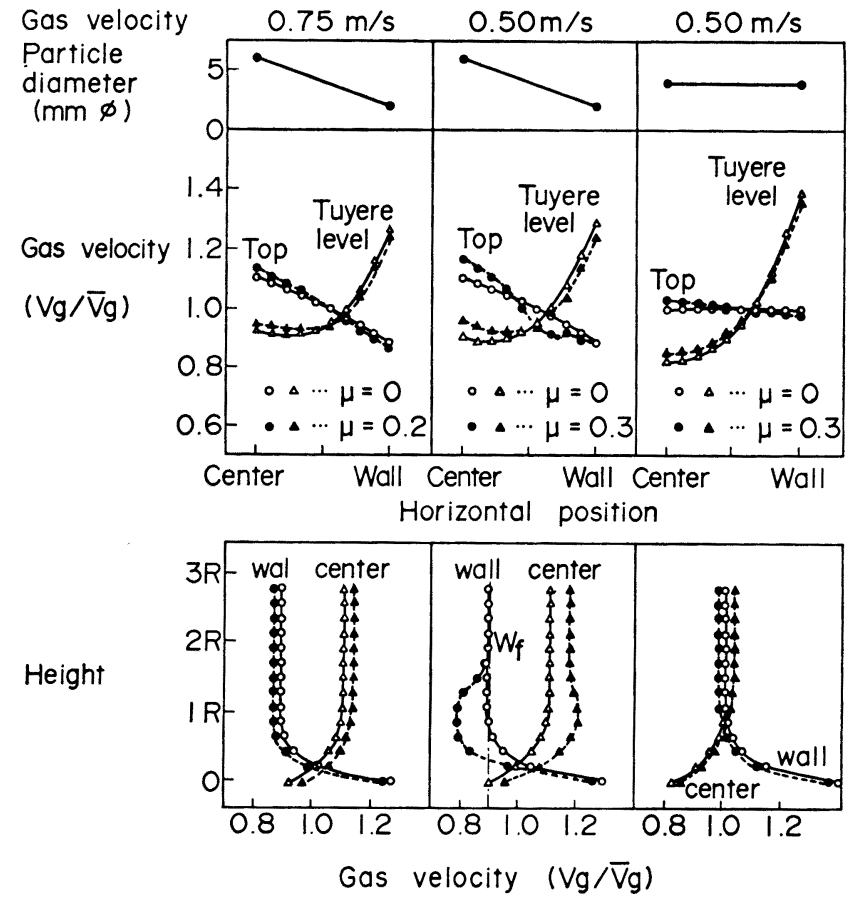

Fig. 10. Distributions of relative vertical gas velocity $\left(V_{g} / V_{g}\right)$ fine particle injection.

の影響がなくなり，通気抵抗に応じた流速分布になる。

一方，前報で示したように，粉滞留領域が形成される 条件は，ガス流速の垂直成分が上方へ移行するとともに 低下し，最終的に粉の終端速度以下になることである。

したがつて，壁側に細粒を偏在させたりガス量を低下 させて壁側のガス流速垂直成分を粉の終端速度以下にす ると, 羽ロレベルからその上方 $0.7 \mathrm{R}$ をでの壁側に粉滞 留領域が形成されることになる.

(12) 式に(5)，（7) 式を代入し， $\varepsilon_{k}=1$ として垂直成 分のタに着目すれば, 本数学モデルにおける単一粒子の 空搭基準の終端速度 $W_{f}$ として次式を得る。

$$
W_{f}=\varepsilon_{p}\left(\frac{g \rho_{k} d_{k} \phi_{k}}{1.75 \rho_{g}}\right)^{1 / 2}
$$

上式に従えば $\varepsilon_{p}=0.4$ の充填層内にお打る直径 0.1 $\mathrm{mm}$, 密度 $2500 \mathrm{~kg} / \mathrm{m}^{3}$ の単一ガラス球粉の空気に対す る終端速度は， $0.44 \mathrm{~m} / \mathrm{s}$ と算定され，上記の条件を満 足寸るBにおいてのみ粉滞留領域が形成されることにな る.

\section{$4 \cdot 2$ 減産高炉における不活性帯形成現象の分析}

小倉 2 高炉では, 昭和 57 年以降の減産過程におい

て, Fig. 11 に示すように, 炉況悪化現象を発生した。 この特徵は以下の 3 点である.
1) 出銑比が $1.5 \mathrm{t} /\left(\mathrm{dm}^{3}\right)$ ，ボッシュガス流速が 1.9 $\mathrm{m} / \mathrm{s}$ を下回る段階からスリップ頻度の増大と通気抵抗 $K R^{7)}$ の悪化に代表される炉沅悪化が発生した。

2）このとき，全圧力損失に占める炉下部圧力損失の 比率が増大しているとともに，ボッシュ部の炉壁温度低 下も顕著である.

3）対策として，ムーバブルアーマを操作して炉壁流 強化を図ることにより炉況悪化が緩和された。

このよらな炉下部の炉壁温度低下を伴ら炉況悪化現象 は一般に炉下部不活性帯と称され，炉壁部の融着帯低下 に起因すると考えられているが8)9)，この例の場合，炉壁 部の融着帯を低下させる直接の原因は明確ではない。

一方，前節で説明した壁側に羽口を有する平板充填層 内に打ける固気 2 相流の特性は高炉に相当する円筒の充 填層にも定性的には共通するものである，そこで，前節 に示した固気 2 相流の特性と照合すれば，高炉下部不活 性化に対する一つの仮説として以下の解釈も成立しら る.

すなわち，減産によりガス量が低下したために羽口上 方に粉滞留領域が生成して炉壁近傍のガス流れを阻害し た結果, 通気抵抗の増大, 炉壁温度の低下, および炉壁 側の融着帯低下をひきおこすとともに, 融着帯中の半溶 


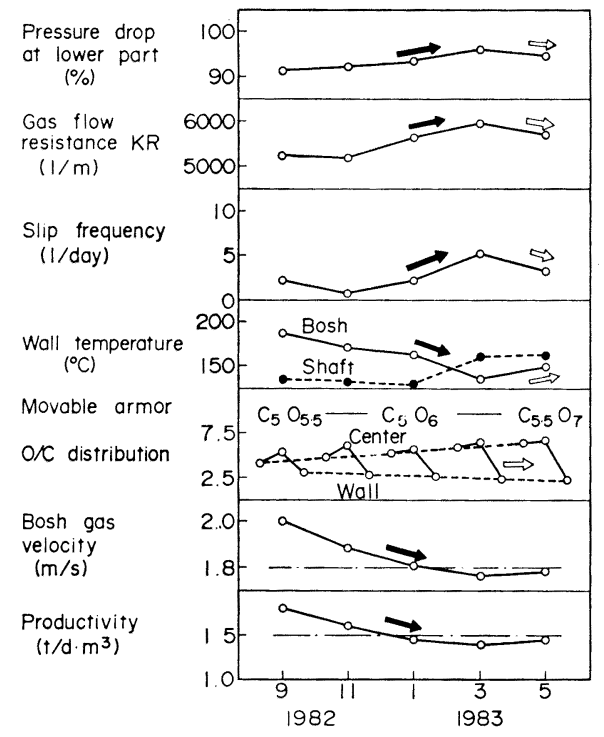

Fig. 11. Change in operation indicies during the reduced production operation of Kokura No. 2 blast furnace.

融物が滞留している粉と混成して付着物を形成し，スリ ップ頻度の増加を誘発したとする解釈である.

师下部におけるコークス充填層の空陌寸法に関するデ 一タが少ないため, コークス粒度を $30 \mathrm{~mm}$, 充填構造を 面心立方格子と仮定して概算すると, 直径約 $4.6 \mathrm{~mm}$ の 粉が通過しらる空隙が存在することになる. 他方, ボッ シュガス流速が約 $1.9 \mathrm{~m} / \mathrm{s}$ を下回る段階から炉況悪化 現象が発生していることに着目し, 粉コークス密度 $1000 \mathrm{~kg} / \mathrm{m}^{3}$, 形状係数 0.7, ユ ークス充填層空隙率 $\varepsilon_{p}$ $=0.4$, ガス密度 $0.6 \mathrm{~kg} / \mathrm{m}^{3}$ の数值を(15) 式に代入し, 終端速度 $W_{f}$ が $1.9 \mathrm{~m} / \mathrm{s}$ に相当する粉コークスの直径 を概算すれば約 $4 \mathrm{~mm}$ となり，上記の解釈と矛盾しな い値になる。

\section{5. 結}

充填層内固気 2 相流の 2 次元挙動を予測する数学モデ ルを作成し，平板模型奏験と対比させてその妥当性を確 認するとともに，粉とガスの流動特性を調查し，以下に 示す結果を得た.

1) 粉とガス，およびガスと充媜䊀子との相互作用力 として Ergun タイプの流体抵抗力, 充填粒子と粉との 相互作用力として両者の衝突に起因する運動量の变化を 適用した数学モデルにより平板充媜層内におけるガスと 粉の 2 次元挙動を予測することができた.
2）計算と実験の結果，壁側に羽口を有する充填層の 場合，壁側に細粒を偏在させたりガス流量を低下させて 壁沿いのガス流速を粉の終端速度以下に低下させると壁 沿いの羽口上方に粉の滞留する領域が形成され，その部 位のガス流れが阻害されることが判明した.

3）減産高炉における炉下部不活性化原因に対する仮 説として，減産によりガス量が低下したため炉壁側のガ ス流速が低下し，羽口上方に粉滞留領域を形成して炉壁 部のガス流れを阻害したためとする固気 2 相流の観点か らの解釈も成立しらることが示された。

以上のように, 高炉の安定操業上粉の挙動は無視でき ない問題であり, 今後, 粉の発生, 消滅機構も考慮して, その影響を総合的に検討する必要があると考えられる。

\section{記号}

$d_{k}, d_{b}:$ 粉および充媜粒子の直径 (m)

$e_{k, p}$ : 衝突における反発係数 (一)

$\vec{F}_{k, g}, \vec{F}_{g, p}, \vec{F}_{p, k}$ : 粉とガス, ガスと充填粒子および 充填粒子と粉之の相互作用力 $\left(\mathrm{kg} / \mathrm{m}^{2} \mathrm{~s}^{2}\right)$

$\vec{g}$ : 重力加速度 $\left(\mathrm{m} / \mathrm{s}^{2}\right)$

$H_{k}, H_{g}:$ 粉およびガスの滞留量 $\left(\mathrm{kg} / \mathrm{m}^{3}\right)$

$P_{g}:$ ガス圧力 $\left(\mathrm{kg} / \mathrm{m}^{2} \mathrm{~s}^{2}\right)$

$R:$ ガス定数 $\left(\mathrm{m} / \mathrm{s}^{2} \mathrm{deg}\right)$

$T_{g}:$ ガス温度 $(\mathrm{deg})$

$\vec{U}_{k}, \vec{U}_{g}:$ 粉およびガスの流速 $(\mathrm{m} / \mathrm{s})$

$V_{g}:$ ガス流速の垂直成分 $(\mathrm{m} / \mathrm{s}$. bed $)$

$W_{f}:$ 粉の終端速度 $(\mathrm{m} / \mathrm{s}$. bed)

$\varepsilon_{k}:$ 粉の空隙率 (ガスの占有容積/充填勫内空隙容 積)

$\varepsilon_{p}:$ 充塤層空隙率（充填層内空隙容積/充填層全容 積)

$\mu$ : 固気比（粉の質量流量/ガスの質量流量）

$\mu_{g}$ : ガスの粘性係数 $\left(\mathrm{kg} / \mathrm{m}^{2} \mathrm{~s}\right)$

$\phi_{k}, \phi_{p}$ : 粉おょび充媜粒子の形状係数 (一)

$\rho_{k}, \rho_{g}, \rho_{p}:$ 粉, ガスおよび充填粒子の密度

$\left(\mathrm{kg} / \mathrm{m}^{3}\right)$

\section{交献}

1) 清水英男, 佐藤憲一, 小島正光, 網永洋一, 中村 交夫，岩永祐治：鉄と鋼, 72 (1986), p. 195

2) 森川 信：流体一固体 2 相流 (1979), p.1 [日刊 工業新聞社]

3) 松本 繁: 化学工学, 50 (1986), p.231

4) L. S. FAN, M. Toda and S. SAtija: Powder Technology, 36 (1983), p. 107

5) 山岡秀行: 鉄と鋼, 72 (1986), p.403

6) 高橋亮一: コンピュータによる流体力学〈演習 $>$ (1982), p.214[(株) 構造計画研究所】

7）的場祥行, 下田輝久：鉄と鋼，60 (1974), S354

8）日本鉄鋼協会共同研究会：第 62 回製銑部会 (1983 年 5 月）新日本製鉄（株）（私信）

9）日本鉄鋼協会共同研究会：第 62 回製銑部会 （1983年 5 月）川崎製鉄（株）（私信） 